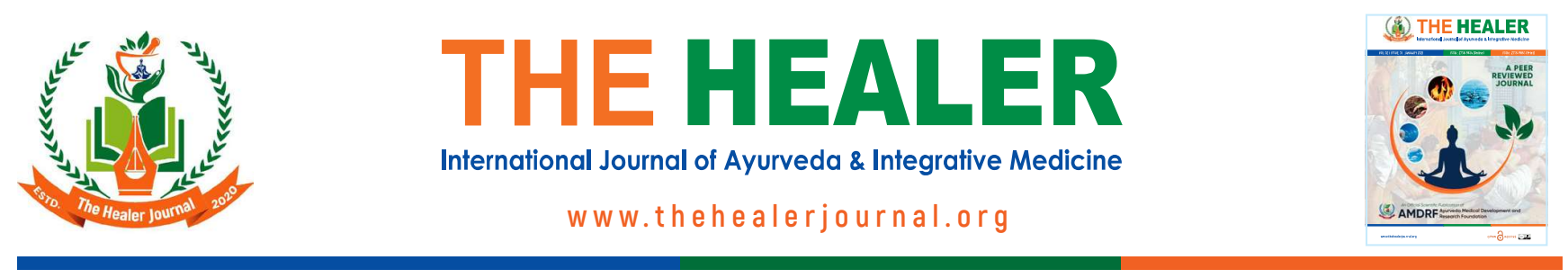

ORIGINAL ARTICLE

\title{
Anatomical Understanding of Vitapa Marma by Means of Cadaveric Dissection
}

\author{
Jeevan Kumar Giri ${ }^{1 *}$, Anju Thomas ${ }^{2}$, Pratikshya Majagaiyan ${ }^{3}$ \\ Uma. B. Gopal ${ }^{4}$ Hari Saran Aryal ${ }^{5}$
}

\begin{abstract}
${ }^{1}$ Teahing Assistant, Ayurveda Campus,IOM,TU, Kathmandu, ${ }^{2}$ Associate professor, ${ }^{4}$ Professor \& HOD - Department of Rachana Sharir Sri Dharmasthala Manjunatheshwara College of Ayurveda \& Hospital, Hassan -573201, ${ }^{3}$ Assistance Professor, Department of Shalakya Tantra, Nepal Sanskrit University, Institute of Ayurveda, Central Ayurveda Campus, Beljhundi, Dang, Nepal. 5 PG Scholar, Ayurveda Campus, IOM, TU, Kirtipur.
\end{abstract}

\section{ABSTRACT:}

Background: Marma are those spots on the body which are painful on application of pressure and shows abnormal pulsation. Marma are conglomeration of muscles, vessels, neuro-connective tissue, bones \& joints. There are 107 Marma. Individual Marma are catagorized on different groups on the basis of various aspects such as Rachananusara, Parinamanusara, Sthananusara, Pramananusara etc. Vitapa Marma is the Adhoshakagata, Vaikalyakara Marma of 1 Anguli Pramana. The explanation of the Vitapa Marma in the classical texts cannot specify the particular anatomical entity so the study is undertaken to fulfill the deficit knowledge.Objectives:To evaluate the Snayu \& Sira component of Vitapa Marma.To evaluate structural entity of Vitapa Marma in relation to given Pramana and Viddha Lakshana. Materials and methods:Cadaveric Study. Observation of the structures exposed during cadaveric dissection and correlation with textual description were done and the conclusion was drawn. Results \& Conclusion: Vitapa Marma lies on the inguinal region at the superficial inguinal ring. The anatomical components of this Marma are the structures related to and passing through superficial inguinal ring.

Keywords: Vitapa Marma, Inguinal region, superficial inguinal ring.

\section{INTRODUCTION}

In the earlier period, the Marma science was more developed in the wars where the warriors used to destroy

\begin{tabular}{|c|c|}
\hline \multicolumn{2}{|c|}{ Access the article online } \\
\hline Quick Responde Code & \\
\hline 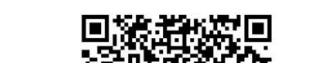 & www.thehealerjournal.org \\
\hline 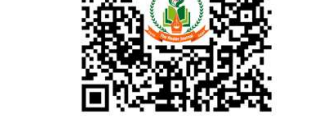 & DOI: 10.51649/healer.44 \\
\hline
\end{tabular}

their enemies by targeting the vulnerable points i.e. Marma points of enemies, since persons injured in the vital spots die immediately; if anyone survives by the efficiency of

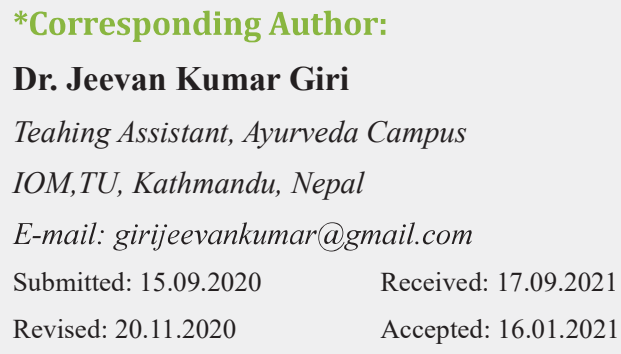


the physician he is sure to suffer from deformities. ${ }^{1}$ Even slight injury to the Marma, will produce severe pain/ troubles; so the diseases localized in the Marma Sthana should be treated with great care and effort by the expertise Vaidya. ${ }^{2}$ Marma are conglomeration of Mamsa, Sira, Snayu, Asthi and Sandhi. ${ }^{3}$ There are 107 Marma. Marmas are classified on different groups on the basis of various aspects. ${ }^{4}$ Sushruta mentioned Vitapa as Snayu Marma ${ }^{4}$ while Vagbhata mentioned it as Sira Marma. ${ }^{5}$ Vitapa Marma is of 1 Angula ${ }^{6,7}$ and is considered as one of the Adha-Shakhagata Marma. ${ }^{4,8}$ Vagbhata mentioned Vitapa is in between Muska and Vamkshana ${ }^{9}$ while Sushruta explain its location between Vamkshana and Vrishana..$^{10}$ Acharya mentioned it as Vaikalyakara Marma. While explaining the Viddha Lakshana of Vitapa Marma Sushruta has mentioned Alpa Shukrata and Shandya. ${ }^{10}$ Vagbhata mention Shandata. ${ }^{11}$ The gross explanation of the Vitapa Marma and different opinions of the Acharyas in the classical text book need to be clarified by analyzing the structural component in the particular region within the area of given pramana. This will be helpful to surgeon to avoid the injury to that Marma while performing surgical interventions.

\section{MATERIALS AND METHODS}

Study Design: The present study was observational gross anatomy in cadaveric conducted in the Dissection Hall of Department of Rachana Sharir of Sri Dharmasthala Manjunatheshwara College of Ayurveda and Hospital, Hassan. Cadaveric Study: By following Cunningham's manual of practical anatomy layer by layer dissection of 3 human cadavers ( 2 male and 1 female) in the inguinal region was done in the dissection hall of Rachana Sharir department, Sri Dharmasthala Manjunatheshwara college $\&$ Hospital, Hassan and observations of Vitapa Marma on the basis of classical description was made and all the necessary information were collected and photographs were taken. Critical analysis of the collected information from the various sources was done. Correlation and critical analysis between those explored structures after dissection and classical description were done and conclusion was drawn.

\section{OBSERVATIONS AND RESULT}

By following the Cunningham's Manual of Practical Anatomy layer by layer dissection of 3 human cadavers was done and the observation of the dissection is listed in the table number 1 :
Superficial inguinal ring and the structures passing though the superficial ring i.e. spermatic cord in male, round ligament of uterus in female and ilioinguinal nerve in both lies in the marked area of the Vitapa Marma. The average dimension of superficial inguinal ring observed was $1.95 \mathrm{~cm}$ in 1st male cadaver, $1.95 \mathrm{~cm}$ in female cadaver, $1.95 \mathrm{~cm}$ in 2nd male cadaver and 1.95 in 2nd male cadaver. Table no: 2

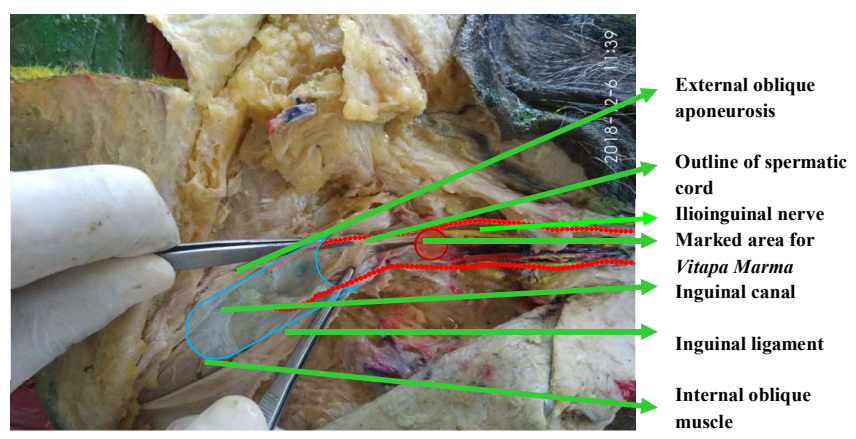

Photograph No: 1 (Male Cadaver)

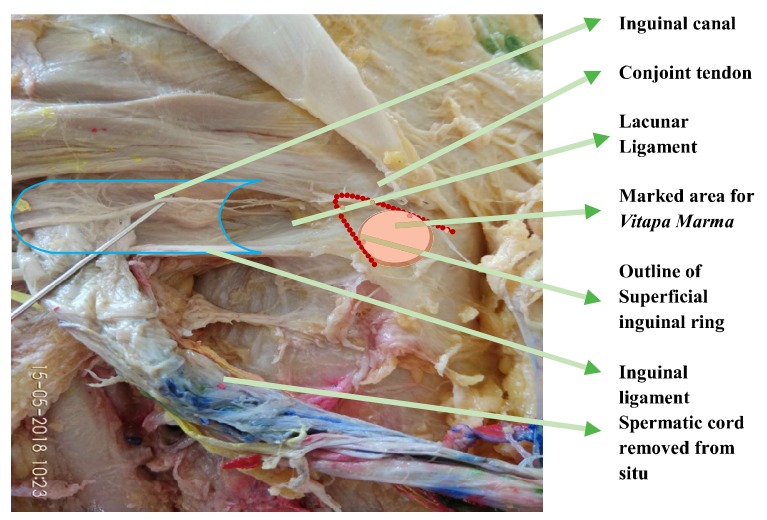
Photograph No: 2 (Male Cadaver)

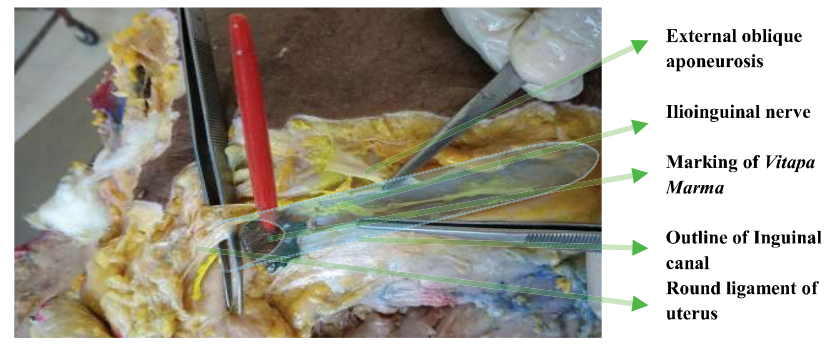

Photograph No: 3 (Female Cadaver)

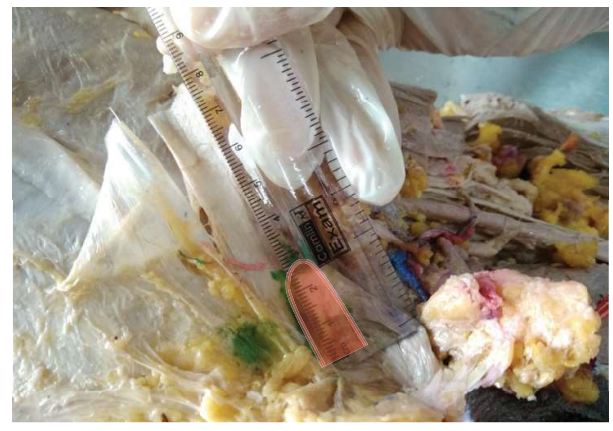

Photograph No: 4 Taking measurement of Superficial inguinal ring 


\section{DISCUSSION}

Vitapa Marma is situated in between Vrishana and Vankshana. ${ }^{10}$ Vagbhata mentioned it's located in between Muska and Vamkshana. ${ }^{9}$ Muska and Vrishana is the scrotal sac enclosing the male gonad i.e. testis. ${ }^{12,13}$ and in case of fema le the homologues organ for the scrotum is labia majora. ${ }^{14}$ At the root of penis a point which indicates the beginning of median raphe of the scrotum which is lower part of pubic symphysis can be taken for the landmark of Vrishana. Vankshana is Adhoshakhagata Sandhi. ${ }^{15}$ which is the hip joint. The landmark given for the hip joint is the mid inguinal point. ${ }^{16}$ The location of the Vitapa Marma may be midway between the mid inguinal point and lower part of pubic symphysis in the groin region at level of superficial inguinal ring. The Vitapa Marma is 1 Angula. One Angula is approximately $2 \mathrm{~cm} .{ }^{17}$ The length of the superficial inguinal ring is $2.5 \mathrm{~cm}$ from apex to base and width is $1.25 \mathrm{~cm}$ at base. ${ }^{18}$ In the present observation the marked area lies at the level of superficial inguinal ring. The average dimension of the superficial inguinal ring is $1.95 \mathrm{~cm}, 1.95 \mathrm{~cm} \& 1.95$ $\mathrm{cm}$ in 1st male, 2nd male and female cadaver respectively. The Anguli Pramana of Vitapa Marma and dimension of superficial inguinal ring is approximately equal to each other so, structural entity of superficial inguinal ring and the structures emerging out through it is Vitapa Marma. Sushruta has mentioned the Vitapa Marma as Snayu Marma. ${ }^{4}$ Snayu are the binding structure in the body that binds the Mamsa, Asthi and Medha. ${ }^{19}$ In the present study the observation made at superficial inguinal ring which was formed as triangular interval of the external oblique aponeurosis beyond pubic tubercle, spermatic cord in male, round ligament in female and ilioinguinal nerve passed through this opening which are the Snayu component. Vagbhata mentioned Vitapa Marma as the Sira Marma. ${ }^{5}$ The structure that allows the continuous flow through it is known as Sira. ${ }^{20,21}$ In the present study superficial and deep external pudendal vessels in both, artery to ductus deferens, testicular artery, cremasteric artery, pampiniform plexus of vein in male, was observed along the region of Vitapa Marma. These may be the Sira component of the Vitapa Marma. Acharya Sushruta and Vagbhata mentioned it as Vaikalyakara Marma. Sushruta mentioned the Viddha Lakshana of Vitapa marma as Alpa Shukrata and Shandya " whereas Vagbhata mentioned Viddha Lakshana as Shandya. ${ }^{22}$ The ductus deferens in the spermatic cord is responsible for transporting the sperm. ${ }^{23}$ If it is obstructed or injured, the sperm flow is obstructed that lead to decreased sperm count or absence of the sperm in semen during ejaculation that affect reproduction. ${ }^{24}$ Testicular artery interruption in the region of the spermatic cord leads to infarction of testis. ${ }^{25}$ Thus, testicular artery and artery for ductus deferens and other arteries and pampiniform plexus of vein are responsible for maintaining the tissue perfusion with nutrition and oxygen. The impact of injury in these particular vessels result in the ischemic condition of the testis, ductus deferens, even the structures of spermatic cord etc. followed by infarction and necrotic changes which ultimately lead to infertility or sterility. The round ligament of the uterus is one of the main mechanical and primary support of the uterus. ${ }^{26}$ The normal position of the uterus is anteversion and anteflexion. Long axis of vagina and long axis of the cervix of uterus forms 90 degree called anteversion. Anti-flexed orientation of uterus is where the long axis of the body of uterus makes an angle of 125 degree with the axis of the cervical canal i.e. forward bending of the uterus on itself. ${ }^{27}$ The ligament pulls the fundus forwards and maintains the anteversion and anteflexion of the uterus. ${ }^{28,29}$ The impact of injury to the round ligament may lead to malposition of uterus, prolapse of the uterus, which ultimately affects the sperm propagation, conception, implantation leading to infertility.

\section{CONCLUSION:}

The Vitapa Marma lies on inguinal region over superficial inguinal ring. Its dimension is $1.95 \mathrm{~cm}$ which is approximately equal to the Pramana of Vitapa Marma which is 1 Anguli. The presence of the neuro-connective tissue such as coverings of the spermatic cord in male, round ligament of uterus in female, ilioinguinal nerve, genital branch of genito femoral nerve, inguinal ligament it is Snayu Marma. The presence of vascular structures and ducts such as pampaniform venous plexus, testicular artery, cremasteric artery, ductus deference in male, it is Sira Marma. So, the superficial inguinal ring and structure passing thorough it can be considered as the Vitapa Marma.

\section{ACKNOWLEDGEMENTS:}

We are sincerely thankful to Dr. Prasanna N. Rao (Professor and Principal of Sri Dharmasthala Manjunatheshwora College of Ayurveda and Hospital, Hassan), Dr. Girish KJ (Professor, Department of Kayachikitsha), Dr. Harini A. (Associate Professor, Department of Dravya Guna) for their 
valuable guidance and supports.

CONFLICT OF INTEREST: Author declares that there is no conflict of interest.

\section{SOURCE OF SUPPORT: None}

\section{REFERENCES:}

1. Sushruta, Sushruta Samhita with Nibandhasangraha commentary of Sri Dalhanacharya \& the Nyayachandrika Panjika of Sri Gayadasacharya on Nidanasthana edited by Vaidya Yadavji Trikamji Acharya. Reprint ed. Varanasi: Chaukambha Sanskrit Sansthan; 2010. (Shareerasthana 6th chapter) p.37178.

2. Sharma SP. Astanga Sangraha with Sasilekha Sanskrit commentary of Indu.2nd ed. Varanasi (India): Chaukambha Orientalia; 2008. p.326.

3. Vagbhata. Astanga Hridayam Vidhyotini Tika, Sharirasthana, Gupt A. editor Varanasi: Chowkhamba Prakashan; Reprint 2009.p.268.

4. Sushruta, Sushruta Samhita with Nibandhasangraha commentary of Sri Dalhanacharya \& the Nyayachandrika Panjika of Sri Gayadasacharya on Nidanasthana edited by Vaidya Yadavji Trikamji Acharya. Reprint ed. Varanasi: Chaukambha Sanskrit Sansthan; 2010. (Shareerasthana 6th chapter) p.369.

5. Murthy KRS. Astanga Hridayam Sutrasthana and Sharirasthana Test and English Translation. 2nd ed. Vol. 1. Varanasi: Chowkhamba Krishnadas Academy Publication; 1994.p.428.

6. Ghanekar BG. Sushruta Samhita Shareerasthanam Sanskrit Text with Ayurvedarahasyadipika Hindi Commentary. Reprint ed, New Delhi (India): Meharchand Lachmandas Publication; 2014. (Shareerasthana 6th chapter).p.180-200.

7. Vagbhata. Astangahridayam with the commentaries sarvangasundara of Arunnadatta and Aurvedarasayan of Hemadri Sharirasthana; 9th ed. Varanasi: chaukhambha orientalia; Reprint 2005.p.415.

8. Ghanekar BG. Sushruta Samhita Shareerasthanam Sanskrit Text with Ayurvedarahasyadipika Hindi Commentary. New Delhi (India): Meharchand Lachmandas Publication; Reprint 2014.p.183-86.
9. Murthy KRS. Astanga Hridayam Sutrasthana and Sharirasthana Test and English Translation. 2nd ed. Vol. 1. Varanasi: Chowkhamba Krishnadas Academy Publication; 1994.p.423.

10. Ghanekar BG. Sushruta Samhita Shareerasthanam Sanskrit Text with Ayurvedarahasyadipika Hindi Commentary. New Delhi (India): Meharchand Lachmandas Publication; Reprint 2014.p.190.

11. Vagbhata, Astanga Hridayam Vidhyotini Tika, Sharirasthana, Gupt A. editor Varanasi: Chowkhamba Prakashan; Reprint 2009.p.268.

12. Chaurasia BD. B D Chaurasia's Human Anatomy Regional and Applied. 4th ed. Garg DK, editor. Vol. 2. Delhi: Satish Kumar Jain for CBS Publishers and Distributers; 2004.p.234.

13. Williams Sir M. Monier. A Sanskrit-English Dictionary. 1st edition, New Delhi: Bharatya Granth Niketan, reprinted in 2007.p.1011-12.

14. Arushi \& Indu Khurana, BD Chaurasia's Dream Human Embryology, 2nd edition. Krishna Garg, editor. Delhi, CBS Publishors \& Distributors Pvt Ltd; 2012.p.199-200.

15. K.R. Srikantha Murthy,Illustrated Sushruta SamhitaText, English translation, Notes, Appendeces and Index, Vol: 1, Reprint ed:2010, Varanasi, Chaukhambha Orientalia.p.88-89.

16. Chaurasia B.D, B D Chaurasia's Human Anatomy Regional and Applied Dissection and clinical, Vol: 2,5th ed; Reprint ed;2009, New Delhi, CBS Publisher and Distributors Pvt. Ltd, p.61.

17. Vishwanath K, Concept of Pramana Shareera with special reference to determine the stature from Prabahu (Brachium), Dissertation. Bangalore: Rajiv Gandhi University of Health Sciences; 2006.

18. Datta K. A. Essential of Human Anatomy (Abdomin and Thorax). 4th ed. Vol. 3. Kolkata: Current Book International; p.126-27\&346.

19. Parasurama Sastri Vidyasagar, Saranghadar Samhita Deepika commentary of Adamalla and Gudarthadipika of Kashirama. 5th ed. Varanasi(India); Chaukhambha Orientalia. 2002. (I.5.55).p.40\&50. 
20. Agnivesh, Charaka Samhita of Chakrapani Datta, edited by Vaidya Jadavaji Trikamji. Reprint ed. Vanarasi, Chaukambha Prakashan, 2013; (Su. 30/12) p.185.

21. K.R. Srikantha Murthy,Illustrated Sushruta SamhitaText, English translation, Notes, Appendeces and Index, Vol: 1, Reprint ed, Varanasi, Chaukhambha Orientalia, 2010 (Verse 20-22).p.123-129.

22. Murthy KRS. Astanga Hridayam Sutrasthana and Sharirasthana Test and English Translation. 2nd ed. Vol. 1. Varanasi: Chowkhamba Krishnadas Academy Publication; 1994.p.430-31,423.

23. Gray H. Gray's Anatomy -The Anatomical Basis of Clinical Practice. 39th ed. Standring S, editor. Spain: Elsevier Churchill Livingstone; 2006.p.1855-56.

24. Bardale Rajesh, Princip;es of Forensic Medicine \& Toxicology. 2nd ed. New Delhi; Jaypee brothers Medical Publishers (P) Ltd; 2017.p.354.

25. Gray H. Gray's Anatomy -The Anatomical Basis of Clinical Practice. 38th ed. Standring S, editor. Spain:
Elsevier Churchill Livingstone; 2006.p.1557.

26. Chaurasia BD. B D Chaurasia's Human Anatomy Regional and Applied. 4th ed. Garg DK, editor. Vol. 2. Delhi: Satish Kumar Jain for CBS Publishers and Distributers; 2004.p.391-394.

27. Datta K. A. Essential of Human Anatomy (Abdomin and Thorax). 4th ed. Vol. 3. Kolkata: Current Book International;p.361 p.

28. Datta K. A. Essential of Human Anatomy (Thorax and Abdomen). 8th ed; 2008, Vol. 1. Kolkata: Current Book International; Reprint 2009.p.127, 364-369 P.

29. Chaurasia BD. B D Chaurasia's Human Anatomy Regional and Applied. 4th ed. Garg DK, editor. Vol. 2. Delhi: Satish Kumar Jain for CBS Publishers and Distributers; 2004.p.391-394.

\section{How to cite this article:}

Giri JK, Thomas A, Majagaiyan P, Gopal UB, Aryal HS, Anatomical Understanding of Vitapa Marma by Means of Cadaveric Dissection, The Healer Journal, 2021;2(1):6873.

\section{Table no: 1 observation of cadaveric dissection}

\begin{tabular}{|c|c|c|c|c|c|}
\hline Cadaver No & Superficial fascia & $\begin{array}{l}\text { Deep to superficial } \\
\text { fascia }\end{array}$ & Inguinal canal & $\begin{array}{l}\text { Posterior wall and floor } \\
\text { of inguinal canal }\end{array}$ & Deep structures \\
\hline $\begin{array}{l}\text { Cadaver } 1 \text { (Male } \\
\text { body) }\end{array}$ & $\begin{array}{l}\text { Superficial circum- } \\
\text { flex iliac vessel, } \\
\text { superficial epigas- } \\
\text { tric vessels and } \\
\text { superficial external } \\
\text { pudendal vessels. } \\
\text { The superficial } \\
\text { external puden- } \\
\text { dal vessels were } \\
\text { passing near to the } \\
\text { marked area. }\end{array}$ & $\begin{array}{l}\text { External oblique } \\
\text { aponeurosis, } \\
\text { inguinal ligament } \\
\text { \& its extensions, } \\
\text { superficial inguinal } \\
\text { ring. } \\
>\quad \text { Superficial inguinal } \\
\text { ring lies at the } \\
\text { marked area. }\end{array}$ & $\begin{array}{l}\text { Ilioinguinal nerve and } \\
\text { spermatic cord } \\
\text { External spermatic } \\
\text { fascia, cremasteric } \\
\text { fascia and internal } \\
\text { spermatic fascia } \\
>\text { Ductus deferens, } \\
\text { artery to ductus } \\
\text { deferens, testicular } \\
\text { artery, pampiniform } \\
\text { venous plexus, } \\
\text { genital branch of } \\
\text { genito-femoral nerve, } \\
\text { remnant of processus } \\
\text { vaginalis }\end{array}$ & $\begin{array}{l}\text { Conjoint tendon, } \\
\text { reflected part } \\
\text { of inguinal } \\
\text { ligament, lacunar } \\
\text { ligament, medial } \\
\text { end of inguinal } \\
\text { ligament and fascia } \\
\text { transversalis } \\
\text { lacunar ligament } \\
\text { and medial end of } \\
\text { inguinal ligament } \\
\text { were observed at } \\
\text { marked area }\end{array}$ & $\begin{array}{l}\text { Pubic bone- } \\
\text { superior pubic } \\
\text { rami, pubic } \\
\text { tubercle, pecten } \\
\text { pubis \& body of } \\
\text { the pubis. } \\
>\text { Pubic crest and } \\
\text { pubic tubercle } \\
\text { was at marked } \\
\text { point }\end{array}$ \\
\hline $\begin{array}{l}\text { Cadaver } 2(\mathrm{Fe}- \\
\text { male body) }\end{array}$ & $\begin{array}{l}\text { Superficial } \\
\text { circumflex iliac } \\
\text { vessel, superficial } \\
\text { epigastric vessels } \\
\text { and superficial } \\
\text { external pudendal } \\
\text { vessels. } \\
\text { The superficial } \\
\text { external pudendal } \\
\text { vessels passed near } \\
\text { to the marked area. }\end{array}$ & $\begin{array}{l}\text { External oblique } \\
\text { aponeurosis, } \\
\text { inguinal ligament, } \\
\text { superficial inguinal } \\
\text { ring } \\
>\text { Superficial inguinal } \\
\text { ring was at the } \\
\text { marked area. }\end{array}$ & $\begin{array}{l}\text { ilioinguinal nerve and } \\
\text { round ligament of } \\
\text { uterus } \\
>\text { Both emerge from } \\
\text { superficial inguinal } \\
\text { ring which was at the } \\
\text { marked area. }\end{array}$ & $\begin{array}{l}>\text { Conjoint tendon, } \\
\text { inguinal ligament } \\
\text { and lacunar ligament } \\
>\begin{array}{l}\text { Lacunar ligament } \\
\text { and medial end of }\end{array} \\
\text { inguinal ligament } \\
\text { was at marked point }\end{array}$ & $\begin{array}{l}>\text { Body of pubic } \\
\text { and superior } \\
\text { ramus of pubis } \\
>\begin{array}{l}\text { Pubic crest and } \\
\text { pubic tubercle }\end{array} \\
\text { was at marked } \\
\text { point }\end{array}$ \\
\hline
\end{tabular}


Giri et. al. : The Healer Journal January 2021; 2(1)

\begin{tabular}{|c|c|c|c|c|c|}
\hline $\begin{array}{l}\text { Cadaver } 3 \\
\text { (Male body) }\end{array}$ & $\begin{array}{l}\text { Superficial circum- } \\
\text { flex iliac vessel, } \\
\text { superficial epigas- } \\
\text { tric vessels and } \\
\text { superficial external } \\
\text { pudendal vessels. } \\
\text { The superficial } \\
\text { external pudendal } \\
\text { vessels passed near } \\
\text { to the marked area. }\end{array}$ & 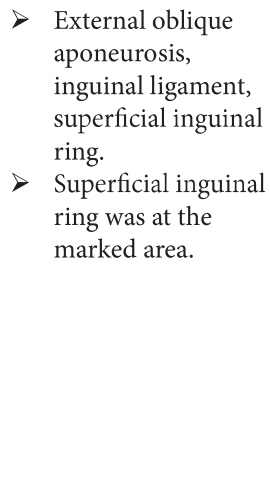 & $\begin{array}{l}>\text { Ilioinguinal nerve and } \\
\text { spermatic cord } \\
\text { External spermatic } \\
\text { fascia, cremasteric } \\
\text { fascia and internal } \\
\text { spermatic fascia } \\
>\text { Ductus deferens, } \\
\text { artery to ductus } \\
\text { deferens, testicular } \\
\text { artery, pampiniform } \\
\text { venous plexus, genital } \\
\text { branch of genito-fem- } \\
\text { oral nerve, remnant } \\
\text { of processus vaginalis } \\
\text { uperf }\end{array}$ & $\begin{array}{l}\text { Conjoint tendon, } \\
\text { inguinal ligament } \\
\text { and lacunar ligament } \\
\text { Lacunar ligament } \\
\text { and medial end of } \\
\text { inguinal ligament } \\
\text { was at marked } \\
\text { point }\end{array}$ & $\begin{array}{l}\text { Body of pubic } \\
\text { and superior } \\
\text { ramus of pubis } \\
\text { Pubic crest and } \\
\text { pubic tubercle } \\
\text { was at marked } \\
\text { point }\end{array}$ \\
\hline
\end{tabular}

Table no:2 Measurement of Superficial inguinal ring

\begin{tabular}{|c|c|c|c|c|c|c|c|}
\hline \multirow{3}{*}{$\begin{array}{l}\text { Cadaver } \\
\text { no: }\end{array}$} & \multicolumn{4}{|c|}{ Dimension of superficial inguinal ring } & \multicolumn{2}{|c|}{ Average dimension } & \multirow{3}{*}{$\begin{array}{l}\text { Average di- } \\
\text { mension of } \\
\text { both side } \\
=(\mathrm{R}+\mathrm{L}) / 2\end{array}$} \\
\hline & \multicolumn{2}{|c|}{ Right side } & \multicolumn{2}{|c|}{ Left side } & \multirow{2}{*}{$\begin{array}{l}\text { Right side } \\
\mathrm{R}=(\mathrm{vr}+\mathrm{hr}) / 2\end{array}$} & \multirow{2}{*}{$\begin{array}{l}\text { Left side } \\
\mathrm{L}=(\mathrm{v}- \\
\mathrm{l}+\mathrm{hl}) / 2\end{array}$} & \\
\hline & $\begin{array}{l}\text { Vertical } \\
\text { extension } \\
\text { (vr) }\end{array}$ & $\begin{array}{l}\text { Horizontal } \\
\text { extension } \\
\text { (hr) }\end{array}$ & $\begin{array}{l}\text { Vertical } \\
\text { extension } \\
(\mathrm{vl})\end{array}$ & $\begin{array}{l}\text { Horizontal } \\
\text { extension } \\
\text { (hl) }\end{array}$ & & & \\
\hline 1. & $2.6 \mathrm{~cm}$ & $1.5 \mathrm{~cm}$ & $2.4 \mathrm{~cm}$ & $1.3 \mathrm{~cm}$ & $2.05 \mathrm{~cm}$ & $1.85 \mathrm{~cm}$ & $1.95 \mathrm{~cm}$ \\
\hline 2. & $2.4 \mathrm{~cm}$ & $1.9 \mathrm{~cm}$ & $2.6 \mathrm{~cm}$ & $1.4 \mathrm{~cm}$ & $1.9 \mathrm{~cm}$ & $2 \mathrm{~cm}$ & $1.95 \mathrm{~cm}$ \\
\hline 3. & $2.6 \mathrm{~cm}$ & $1.5 \mathrm{~cm}$ & $2.4 \mathrm{~cm}$ & $1.3 \mathrm{~cm}$ & $2.05 \mathrm{~cm}$ & $1.85 \mathrm{~cm}$ & $1.95 \mathrm{~cm}$ \\
\hline \multicolumn{7}{|c|}{ Average dimension of superficial Inguinal Ring } & $1.95 \mathrm{~cm}$ \\
\hline \multicolumn{8}{|c|}{ v-vertical extension, h-horizontal extension, r-right, l-left } \\
\hline
\end{tabular}

